\title{
Analisis Kesulitan Belajar Siswa (Disleksia dan Disgrafia) di Masa Pandemi Covid-19
}

Nik Haryanti ${ }^{1}$, Muhibbudin ${ }^{2}$, Imam Junaris ${ }^{3}$

1,2 IAI Pangeran Diponegoro Nganjuk

${ }^{3}$ UIN Satu Tulungagung

*Email: nikharyanti1983@gmail.com (Corresponding Author)

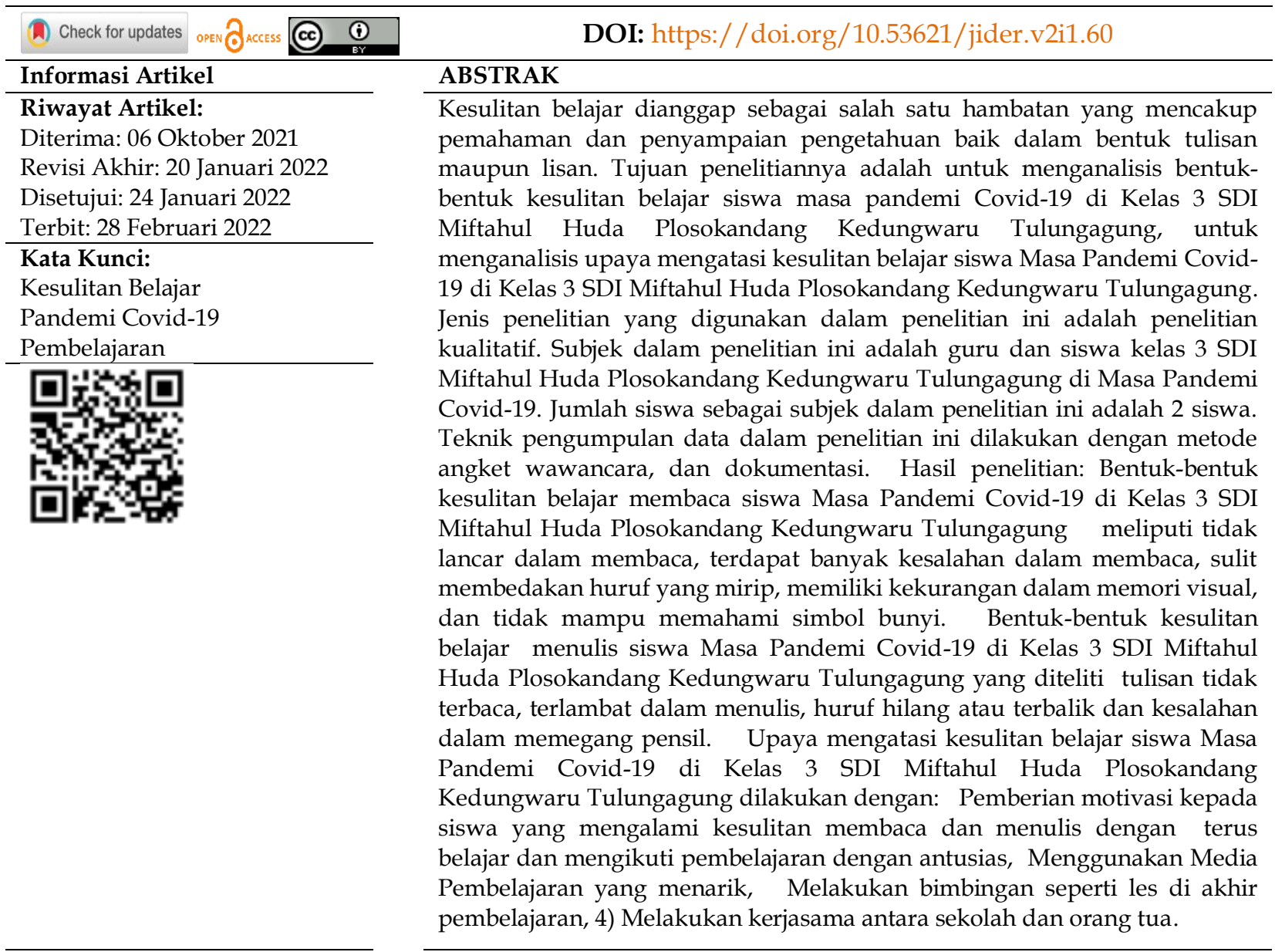

\section{PENDAHULUAN}

Pandemi Covid-19 merupakan sebuah wabah virus yang menyerang manusia dan hewan, akibat virus ini bisa menyebabkan penyakit infeksi saluran pernapasan mulai flu biasa hingga penyakit yang serius (Cahyati \& Kusumah, 2020). Virus Covid-19 ini pertama kali terdeteksi mulai tanggal 7 Januari 2019 didaerah Wuhan Negara China dan cepat menyebar, yang berakibat tidak hanya negara China yang terdampak namun juga mulai menyebar ke negara-negara lain di dunia termasuk di Indonesia. Peristiwa ini berdampak pada seluruh bidang kehidupan, salah satunya adalah lumpuhnya bidang pendidikan.

Pemerintah khawatir melihat semakin banyaknya korban yang terkena virus Covid19. Dampak dari penyebaran ke daerah-daerah lainnya membuat pemerintah mengambil langkah cepat yaitu dengan perintah untuk mengurangi berkerumun pada masyarakat, 
karena virus ini dapat menyebar dengan mudah antar satu orang ke orang lainnya (Lilawati, 2020).

Upaya mencegah persebaran virus Covid-19 di Indonesia berdasarkan panduan penyelengaraan pembelajaran Tahun Ajaran 2020 - 2021 dan Tahun Akademik 2020 - 2021 dimasa pandemi Corona Virus Disease 2019 (Covid-19) oleh Menteri Pendidikan dan Kebudayaan, Menteri Agama, Menteri Kesehatan, dan Menteri Dalam Negeri Republik Indonesia terdapat 4 pengelompokan zona pandemi Covid-19 yaitu zona hijau, zona oranye, zona kuning, dan zona merah. Kabupaten Tulungagung per tanggal 10 Agustus 2020 termasuk ke dalam zona oranye, sehingga berdasarkan Surat Edaran Kepala Dinas Pendidikan Pemuda dan Olahraga pada tanggal 12 Agustus 2020 kegiatan belajar mengajar bertatap muka pada satuan pendidikan tidak boleh dilaksanakan sampai situasi kondusif kembali. Kegiatan pembelajaran dilaksanakan dengan sistem Pembelajaran Jarak Jauh (PJJ). Pada tanggal 20 November 2020, Kementriaan Pendidikan dan Kebudayaan melalui Siaran Pers nomor 368/sipres/A6/XI/2020 memberikan kewenangan penuh kepada Pemerintah Daerah untuk memberikan izin pembelajaran tatap muka pada tahun ajaran 2020 - 2021 semester kedua, mulai bulan Januari 2021. Pemerintah izin pembelajaran tatap muka dapat dilakukan secara serentak dalam satu wilayah kabupaten/kota atau bertahap per wilayah kecamatan dan desa. Kebijakan - Kebijakan bari akan terus dibuat pada masa pandemi hingga tatanan kehidupan kembali normal. Hal ini sangat berpengaruh kepada aktivitas belajar siswa.

Pandemi covid-19 mengakibatkan siswa harus belajar dari rumah. Belajar dari rumah ini menggunakan pembelajaran secara daring, pembelajaran daring yaitu sebuah kegiatan pembelajaran sesuai kurikulum yang ada dengan pelaksanaan pembelajaran tidak berada di sekolah. Pembelajaran daring adalah sebuah pembelajaran dengan menggunakan jaringan internet yang bertujuan untuk memunculkan interaksi dalam pembelajaran (Sadikin \& Hamidah, 2020). Meskipun pembelajaran dilakukan secara daring siswa tetap mendapatkan haknya seperti pada halnya pembelajaran biasa.

Sistem pembelajaran daring dilaksanakan melalui perangkat personal computer (PC) atau laptop yang terhubung dengan koneksi jaringan internet ataupun melalui handphone. Para pendidik dapat melangsungkan pembelajaran bersama di waktu yang sama menggunakan grup di media sosial seperti WhatsApp (WA), telegram, instagram, aplikasi Zoom ataupun media lainnya sebagai media pembelajaran (Subarkah \& Salim, 2021).

Pendidikan melakukan penyesuaian pada masa pandemi covid-19 secara tiba-tiba dan langsung harus diterapkan tentunya membuat pendidik harus mencoba-coba metode maupun alat bantu untuk menyelenggarakan pembelajaran secara daring. Guru harus berinovasi dengan cepat menyelenggarakan proses pembelajaran daring agar kegiatan pembelajaran tidak berbeda dengan yang diselenggarakan secara luar jaringan (luring). Dalam proses ini, guru tentu mencoba satu metode ke metode lain yang dirasa paling cocok untuk menunjang proses pembelajaran secara daring (Winarti, 2021).

Kegiatan pembelajaran di sekolah dasar belum dapat dikatakan berhasil sepenuhnya, hal ini dapat di lihat dari beberapa siswa kelas 3 SDI Miftahul Huda Plosokandang Kedungwaru Tulungagung kesulitan belajar yang dialami siswa berdasarkan hasil observasi awal dan wawancara awal diperoleh informasi bahwa masih banyak siswa yang mengalami kesulitan belajar dengan indikasi yaitu 1) mengalami 
kesulitan membaca (disleksia), terdapat anak mengalami kesulitan dalam hal mengeja suku kata, membaca huruf sering tertukar (huruf ' $b$ ' dibaca ' $d$ ', huruf ' $w$ ' dibaca huruf ' $m$ ') serta tidak mampu mengikuti kecepatan atau ritme teman sekelasnya saat kegiatan membaca. 2) mengalami kesulitan menulis (disgrafia) yaitu masih ada siswa yang ada yang mengalami kesalahan dalam menulis yang seharusnya ' $b$ ' ditulis ' $d$ ', seharusnya ditulis huruf ' $w$ ' ditulis huruf ' $m$ '.

Faktor kesulitan belajar siswa dapat di lihat pasca wabah pandemi covid-19 yang mengharuskan kegiatan pembelajaran online melalui via whatsapp group ini dilakukan untuk mengganti kegiatan pembelajaran secara langsung yakni ketika pada saat guru memberikan soal maupun materi masih banyak siswa yang pasif sehingga kegiatan pembelajaran menjadi kurang maksimal, sering terjadi gangguan jaringan pada penggunaan whatsapp, dan bagi siswa yang kurang aktif pada saat diskusi di media whatsapp group juga mengalami kesulitan karena banyak ketertinggalan materi pembelajaran terutama bagi siswa yang cenderung memiliki pemahaman rendah sehingga hal-hal tersebut dapat mempengaruhi kesulitan belajar siswa (Putri, Saragih, \& Astuti, 2021)

Kesulitan belajar dianggap sebagai salah satu hambatan yang mencakup pemahaman dan penyampaian pengetahuan baik dalam bentuk tulisan maupun lisan. Menurut Zamzami, Sakdiah, \& Nurbaiza (2020) “anak yang mengalami kesulitan belajar merupakan anak yang memiliki gangguan dalam hal penerimaan pelajaran dan penggunaan bahasa lisan atau tulisan, yang meliputi kemampuan pendengaran, kemampuan berpikir, kemampuan berbicara, kemampuan membaca, kemampuan menulis dan mengeja, serta kemampuan menghitung tidak sempurna".

Faktor kesulitan belajar berdampak pada ketidakberhasilan proses pembelajaran yang mengakibatkan adanya kegagalan belajar pada siswa. Adapun faktor penyebabnya ialah faktor internal dan faktor eksternal. Faktor internal siswa dapat dilihat dari hal-hal atau keadaan yang muncul dari dalam diri siswa sedangkan faktor eksternal dapat dilihat dari keadaan yang datang dari luar diri siswa (Zamzami et al., 2020).

Dampak faktor kesulitan belajar secara rinci pada siswa, yaitu rendahnya hasil belajar, lambat menyelesaikan tugas yang diberikan, menunjukkan sikap yang kurang wajar, meunjukkan tingkah laku seperti membolos, datang terlambat, tidak mengerjakan PR, dan mengganggu teman di dalam ataupun di luar kelas (Simanjuntak, Ritonga, \& Harahap, 2020).

Selama proses pembelajaran daring berlangsung pasti menghadapi berbagai kesulitan atau kendala. Salah satunya kendala pembelajaran daring adalah layanan jaringan internet, peserta didik belum terbiasa dengan pembelajaran daring, fasilitas yang ada dirumah yang menunjang pembelajaran daring dan lain sebagainya. Jaringan internet yang kurang stabil dapat memengaruhi proses belajar peserta didik (Jamal, 2014). Pembelajaran yang dilaksanakan di rumah membuat peserta didik kurang termotivasi untuk belajar karena pembelajaran daring tidaklah seperti pembelajaran konvensional yang bisa tatap muka dengan guru serta perserta didik lainnya Pelaksanaan pembelajaran daring belum tentu peserta didik focus dalam pembelajaran karena mengalami kesulitan misalkan kestabilan jaringan internet yang mengganggu proses pembelajaran, kurang focus karena kondisi rumah yang ramai, dan lain sebagainya (Nabila \& Sulistiyaningsih, 2020). 
Permasalahan kesulitan belajar yang terjadi pada siswa kelas 3 SDI Miftahul Huda Plosokandang Kedungwaru Tulungagung mengenai 1) disleksia terjadi pada siswa dengan gejala mengalami masalah membaca yang lambat dan mempunyai tulisan yang kurang bagus, 2) disgrafia terjadi pada siswa dengan gejala siswa kurang dapat memegang pensil dengan benar atau tulisannya jelek dan mengalami kesulitan dalam mengharmonisasikan ingatan dengan penguasaan gerak ototnya secara otomatis saat menulis huruf dan angka.

Beberapa penelitian yang telah dilakukan oleh peneliti sebelumnya juga menemukan kesulitan belajar siswa yang dihadapi selama masa pandemic covid 19. Diantaranya penelitian yang dilakukan Satrianawati (2012) disleksi, disgrafia, dan diskalkulia merupakan tiga bentuk kesulitan belajar yang dialami oleh anak.Diskalkulia merupakan bentuk kesulitan belajar yang dialami anak dalam belajar matematika. Hampir semua siswa mengatakan bahwa matematika merupakan mata pelajaran yang paling sulit. Jika tidak sulit itu berarti bukan pelajaran matematika. Penelitian yang dilakukan oleh Husein (2020) kesulitan belajar yang dialami adalah dibidang membaca dan menulis. Dengan mengetahui bentuk-bentuk kesulitan belajar guru dapat memilih jenis intervensi yang tepat, efektif dan efisien untuk diberikan dalam membantu siswa mengatasi kesulitan belajarnya. Penelitian Wijaya (2020) menyebutkan ketidakmampuan membaca (disleksia), menulis (disgrafia), maupun berhitung (diskalkulia) merupakan domain dari gangguan belajar spesifik pada anak.

Penelitian ini dilakukan untuk menjawab permasalahan bagaimana bentuk-bentuk kesulitan belajar membaca siswa Masa Pandemi Covid-19 dan upaya mengatasi kesulitan belajar siswa Masa Pandemi Covid-19 di Kelas 3 SDI Miftahul Huda Plosokandang Kedungwaru Tulungagung?

Tujuan penelitiannya adalah untuk menganalisis bentuk-bentuk kesulitan belajar siswa Masa Pandemi Covid-19 di Kelas 3 SDI Miftahul Huda Plosokandang Kedungwaru Tulungagung dan untuk menganalisis upaya mengatasi kesulitan belajar siswa Masa Pandemi Covid-19 di Kelas 3 SDI Miftahul Huda Plosokandang Kedungwaru Tulungagung.

\section{METODE PENELITIAN}

Pendekatan penelitian yang digunakan pada studi ini adalah pendekatan kualitatif. Metode kualitatif sebagai prosedur penelitian yang menghasilkan data deskriptif berupa kata-kata tertulis atau lisan dari orang-orang atau perilaku yang dapat diamati (Tanzeh, 2009). Metode kualitatif ini digunakan karena beberapa pertimbangan yaitu metode kualitatif lebih bisa dan mudah menyesuaikan apabila berhadapan dengan kenyataan ganda (Fitri \& Haryanti, 2020), metode ini menyajikan hakikat hubungan antara peneliti dan responden secara langsung dan metode ini lebih peka sehingga dapat menyesuaikan diri dan banyak penajaman pengaruh bersama terhadap pola-pola nilai yang dihadapi peneliti.

Studi kasus juga dapat mengantarkan peneliti memasuki unit-unit sosial terkecil seperti perhimpunan, kelompok, keluarga dan berbagai bentuk unit sosial lainnya. Studi kasus juga berusaha mendeskripsikan suatu latar, objek atau suatu peristiwa tertentu secara mendalam. Studi kasus merupakan strategi yang dipilih untuk menjawab pertanyaan how dan why, jika fokus penelitian berusaha menelaah fenomena kontemporer (masa kini) dalam kehidupan nyata (Siregar, 2017). Adapun alasan peneliti menggunakan studi kasus dalam mengkaji bagaimana kesulitan belajar siswa kelas 3 SDI Miftahul Huda Plosokandang Kedungwaru Tulungagung di Masa pandemi Covid-19.

Subjek penelitiannya adalah guru dan orang tua serta siswa di kelas 3 SDI Miftahul Huda Plosokandang Kedungwaru Tulungagung. Penelitian ini dilaksanakan dalam waktu kurang lebih 2 bulan yaitu mulai penyusunan kerangka pada bulan Mei 2021 sampai 
dengan penyusunan laporan pada bulan Juni 2021. Lokasi penelitian ini adalah di kelas 3 SDI Miftahul Huda Plosokandang Kedungwaru Tulungagung.

Teknik pengumpulan data yang digunakan dalam penelitian ini adalah:

Observasi dilakukan untuk menggali data dari sumber data yang berupa peristiwa, tempat, benda, serta rekaman dan gambar (Abdurrahman, 2009). Dalam penelitian ini dilaksanakan dengan teknik observasi, yaitu dilakukan dengan cara penelitian melibatkan diri atau berinteraksi pada kegiatan yang dilakukan oleh subyek penelitian dalam lingkungannya, selain itu juga mengumpulkan data secara sistematik dalam bentuk catatan lapangan (Sukmadinata, 2011).

Metode observasi pada penelitian ini digunakan untuk mengumpulkan data yang berkaitan dengan rumusan permasalahan. Dalam hal ini peneliti berusaha melakukan suatu pengamatan dan pencatatan secara sistematis terhadap gejala yang tampak di kelas 3 SDI Miftahul Huda Plosokandang Kedungwaru Tulungagung.

Metode wawancara atau interview adalah proses memperoleh keterangan untuk tujuan penelitian dengan cara tanya jawab sambil bertatap muka dengan pihak yang bersangkutan (Sugiyono, 2015). Metode wawancara atau interview untuk penelitian ini digunakan sebagai pedoman dalam melakukan penelitian. dalam hal ini peneliti memakai teknik wawancara mendalam (in deep interview), yaitu dengan menggali informasi mendalam mengenai upaya guru dalam menanggulangi pengaruh negatif perkembangan teknologi informasi. Peneliti akan mewawancarai guru dan orang tua serta siswa di kelas 3 SDI Miftahul Huda Plosokandang Kedungwaru Tulungagung, guna memperoleh data tentang kesulitan belajar siswa kelas 3 SDI Miftahul Huda Plosokandang Kedungwaru Tulungagung di Masa pandemi Covid-19.

Metode dokumentasi adalah metode yang digunakan untuk mencari data mengenai hal-hal atau variabel-variabel yang berupa catatan, transkrip, buku, surat kabar, agenda atau lain sebagainya (Arikunto, 2016). Pada sebuah penelitian, teknik dokumentasi digunakan sebagai sumber data pendukung. Di samping itu data dokumentasi diperlukan untuk melengkapi data yang diperoleh dari wawancara dan observasi. Peneliti dalam hal ini menggunakan teknik dokumentasi untuk memperoleh data yang berupa arsip-arsip, catatan-catatan, buku-buku yang berkaitan dengan peran orang tua dalam mendukung proses pembelajaran daring. Dokumen yang dimaksud bisa berupa foto-foto, dokumen sekolah, transkrip wawancara, dan dukumen tentang sejarah sekolah serta perkembangnya, ke semua dokumentasi ini akan dikumpulkan untuk di analisis demi kelengkapan data penelitian.

Teknik analisis data adalah upaya yang dilakukan dengan jalan bekerja dengan data, mengorganisasikan data, memilah-milahnya menjadi satuan yang dapat dikelola, mensintesiskannya, mencari dan menemukan apa yang penting dan apa yang dipelajari dan memutuskan apa yang dapat diceritakan kepada orang lain (Moleong, 2002). Menurut Miles dan Huberman (dalam Sugiyono, 2015), bahwa analisis data penelitian kualitatif dapat dilakukan melalui tiga alur kegiatan yang terjadi secara bersamaan yaitu: l) reduksi data (data reduction), 2) penyajian data (data displays dan 3) penarikan kesimpulan/verifikasi (conclusion drawing/ veriffication).

\section{HASIL DAN PEMBAHASAN}

1. Bentuk-bentuk kesulitan belajar siswa Masa Pandemi Covid-19 di Kelas 3 SDI Miftahul Huda Plosokandang Kedungwaru Tulungagung

Berdasarkan hasil penelitian bentuk-bentuk kesulitan belajar membaca siswa Masa Pandemi Covid-19 di Kelas 3 SDI Miftahul Huda Plosokandang Kedungwaru Tulungagung meliputi tidak lancar dalam membaca, terdapat banyak kesalahan dalam 
membaca, sulit membedakan huruf yang mirip, memiliki kekurangan dalam memori visual, dan tidak mampu memahami simbol bunyi.

Menurut Satrianawati (2012) disleksia yaitu kategori bagi individu-individu yang memiliki gangguan parah dalam hal membaca dan mengeja. Banyak orang hanya mengenal istilah disleksia. Hal ini dikarenakan disleksia pada anak lebih mudah dikenali daripada diskalkulia. Disleksia merupakan masalah umum yang menandakan seorang anak mengalami kesulitan dalam belajar membaca. Disleksia mudah dikenali berdasarkan keterampilan fonologis pada anak ketika memadukan bunyi dan huruf dalam membentuk kata-kata.

Disleksia ditunjukkan dengan kesulitan dalam aspek-aspek bahasa yang berbeda, termasuk problem membaca, problem dalam memperoleh kecakapan dalam menulis dan mengeja. Definisi ini memuat beberapa point, yaitu: (1) disleksia adalah salah dari satu kesulitan belajar, (2) kesulitan dalam fonologi, (3) disleksia mencakup problem mengeja dan menulis (Mulyadi, 2010).

Hasil penelitian ini sesuai dengan penelitian Wijaya (2020) Gangguan belajar spesifik yang paling sering terjadi pada anak adalah ketidakmampuan membaca (disleksia) seperti yang dilaporkan pada kasus ini. Identifikasi gangguan belajar pada anak berdasarkan pendekatan klinis dari tiap individu, laporan guru dan catatan akademis serta respons terhadap intervensi. Hasil penelitian mengenai bentuk-bentuk kesulitan belajar menulis siswa Masa Pandemi Covid-19 di Kelas 3 SDI Miftahul Huda Plosokandang Kedungwaru Tulungagung meliputi tulisan tidak terbaca, terlambat dalam menulis, huruf hilang atau terbalik dan kesalahan dalam memegang pensil. Hasil penelitian ini sesuai menurut Santrock (2012) disgrafia sebagai kesulitan belajar yang ditandai dengan adanya kesulitan dalam mengungkapkan pemikiran dalam komposisi tulisan. Pada umumnya, istilah disgrafia digunakan untuk mendiskripsikan tulisan tangan yang sangat buruk. Anak-anak yang memiliki disgrafia mungkin menulis dengan sangat pelan, hasil tulisan mereka bisa jadi sangat tak teerbaca, dan mereka mungkin melakukan banyak kesalahan ejaan karena ketidakmampuan mereka untuk memadukan bunyi dan huruf.

Demikian juga menurut Satrianawati (2012) disgrafia yaitu kesulitan belajar yang mencakup kesulitan dalam hal menulis dengan tangan karakteristik anak dengan disgrafia sebagai berikut: terdapat ketidakkonsistenan bentuk huruf dalam tulisannya; saat menulis, penggunaan huruf besar dan huruf kecil masih tercampur; ukuran dan bentuk huruf dalam tulisannya tidak proporsional;anak tampak harus berusaha keras saat mengkomunikasikan suatu ide, pengetahuan, atau pemahamannya lewat tulisan; sulit memegang bolpoin maupun pensil dengan mantap. caranya memegang alat tulis seringkali terlalu dekat bahkan hampir menempel dengan kertas; berbicara pada diri sendiri ketika sedang menulis, atau malah terlalu memperhatikan tangan yang dipakai untuk menulis; cara menulis tidak konsisten, tidak mengikuti alur garis yang tepat dan proporsional; tetap mengalami kesulitan meskipun hanya diminta menyalin contoh tulisan yang sudah ada (Sa 'adati, 2015).

Secara spesifik penyebab disgrafia tidak diketahui secara pasti, namun apabila disgrafia terjadi secara tiba-tiba pada anak maupun orang yang telah dewasa maka diduga disgrafia disebabkan oleh trauma kepala entah karena kecelakaan, penyakit, dst. 
Disamping itu para ahli juga menemukan bahwa anak dengan gejala disgrafia terkadang mempunyai anggota keluarga yang memiliki gejala serupa. Demikian ada kemungkinan faktor herediter ikut berperan dalam disgrafia.

Banyak individu yang menderita disgrafia biasanya merasakan sakit ketika menulis. Rasa sakit tersebut dimulai dari lengan bagian bawah kemudian menyebar ke sistem syaraf di seluruh tubuh. Ironisnya studi menemukan bahwa para penderita disgrafia jarang mengeluhkan rasa sakitnya tersebut. Hal ini terjadi karena: Anak menganggap rasa sakit tersebut adalah sesuatu yang biasa. Apabila dia tahu bahwa rasa sakit tersebut adalah sesuatu yang tidak normal, mereka berpikir bahwa sedikit orang akan percaya jika penderita menceritakan keluhannya; Sebagian anak disgrafia yang menyadari rasa sakit tersebut akan menganggap hal tersebut sebagai ketidaknyamanan yang bersifat minor; Kemajuan teknologi memungkinkan penderita disgrafia untuk mengetik dan tak perlu banyak menulis. Demikian penderita merasa tak perlu repot mengeluhkan ketidaknyamanannya (Sa 'adati, 2015).

Hasil penelitian ini juga sesuai dengan penelitian Suhartono (2016) Anak-anak disgrafia oleh guru sering dianggap sebagai anak yang bodoh, anak yang malas belajar, anak yang nakal. Akibatnya baik guru maupun anak menjadi frustasi. Padahal sebenarnya anak-anak disgrafia sama dengan anak-anak normal lain. Anak disgrafia juga ingin dapat mengeksresikan dan mentransfer pikiran dan perasaannya ke dalam bentuk tulisan. Hanya saja anak-anak disgrafia ini mengalami hambatan dalam mengungkapkannya ke dalam bentuk tulisan.

2. Upaya mengatasi kesulitan belajar siswa Masa Pandemi Covid-19 di Kelas 3 SDI Miftahul Huda Plosokandang Kedungwaru Tulungagung

Upaya mengatasi kesulitan belajar siswa Masa Pandemi Covid-19 di Kelas 3 SDI Miftahul Huda Plosokandang Kedungwaru Tulungagung dilakukan dengan:

a. Memberikan motivasi

Pemberian motivasi pada anak yang kesulitan dalam membaca dan menulis untuk terus belajar agar bisa mengikuti kegiatan pembelajaran dengan baik, sehingga tidak tertinggal dengan anak-anak yang lainnya.

Hasil penelitian ini sesuai menurut Motivasi sebagai penggerak semangat peserta didik. Selaras dengan pendapat (Yuliandri, 2016) mengemukakan bahwa motivasi adalah penggerak yang ada pada diri peserta didik saat mengikuti belajar mengajar. Selanjutnya menurut Agustina, motivasi adalah dorongan internal dan eksternal peserta didik dengan harapan adanya perubahan tingkah laku.

b. Menggunakan Media Pembelajaran yang menarik

Cara mengatasi kesulitan belajar membaca dan menulis adalah pemilihan media yang menarik dalam pembelajaran. Dalam pembelajaran membaca dan menulis media yang dimanfaatkan yaitu gambar, media cetak dan media alam. Media yang umum digunakan dalam pembelajaran membaca dan menulis yaitu buku paket setara SD, papan tulis dan spidol. Namun pembelajaran menulis juga menggunakan media lainnya, yaitu media gambar dan media alam agar siswa lebih tertarik dengan materi pembelajaran tersebut. Jika hanya menggunakan media buku saja, mereka akan mudah bosan dan jenuh. 
Hasil penelitian ini sesuai menurut (Putra \& Nugroho, 2016) media adalah alat bantu guru dalam proses kegiatan pembelajaran yang bertujuan untuk mempermudah guru dalam hal menyampaikan materi kepada siswa. Selain itu, media pembelajaran bisa membantu siswa untuk menerima materi karena dapat digunakan siswa secara mandiri di rumah. Hal ini selaras dengan pendapat (Ismawati, 2017) mengemukakan bahwa media pembelajaran diartikan sebagai alat bantu proses belajar mengajar dipergunakan untuk merangsang pikiran, perasaan, perhatian dan kemampuan peserta didik. Strategi yang digunakan yaitu menggunakan media pembelajaran menarik seperti media gambar dan media alam. Menurut (Syahruddin, 2010) media gambar adalah media bermanfaat yang digunakan oleh guru dalam proses pembelajaran, karena media ini sederhana dan mudah diperoleh.

c. Melakukan bimbingan seperti les di akhir pembelajaran

Upaya guru dalam mengatasi kesulitan belajar siswa melalui bimbingan les diberikan kepada siswa yang mengalami kesulitan belajar dan menulis dengan mendatangi rumah siswa dengan membuat kelompok.

Hasil penelitian ini sesuai menurut (Supriadi, 2017) sumber belajar merupakan semua sumber pesan, orang bahan, alat, teknik dan latar yang dimanfaatkan sebagai sumber untuk kegiatan belajar dan mengajar.

d. Melakukan kerjasama antara sekolah dan orang tua

Upaya guru dengan melakukan kerjasama antara sekolah dan orang tua dalam membimbing anaknya dalam belajar membaca dan menulis secara rutin dan melibatkan anak secara bertahap dalam mengerjakan tugas sesuai dengan tingkat kesulitannya.

\section{KESIMPULAN}

Bentuk-bentuk kesulitan belajar membaca siswa Masa Pandemi Covid-19 di Kelas 3 SDI Miftahul Huda Plosokandang Kedungwaru Tulungagung meliputi tidak lancar dalam membaca, terdapat banyak kesalahan dalam membaca, sulit membedakan huruf yang mirip, memiliki kekurangan dalam memori visual, dan tidak mampu memahami simbol bunyi. Bentuk-bentuk kesulitan belajar menulis siswa Masa Pandemi Covid-19 di Kelas 3 SDI Miftahul Huda Plosokandang Kedungwaru Tulungagung yang diteliti tulisan tidak terbaca, terlambat dalam menulis, huruf hilang atau terbalik dan kesalahan dalam memegang pensil. Upaya mengatasi kesulitan belajar siswa Masa Pandemi Covid-19 di Kelas 3 SDI Miftahul Huda Plosokandang Kedungwaru Tulungagung dilakukan dengan: 1) Pemberian motivasi kepada siswa yang mengalami kesulitan membaca dan menulis dengan terus belajar dan mengikuti pembelajaran dengan antusias, 2) Menggunakan Media Pembelajaran yang menarik, 3) Melakukan bimbingan seperti les di akhir pembelajaran, 4) Melakukan kerjasama antara sekolah dan orang tua.

\section{REKOMENDASI}

Berdasarkan hasil penelitian analisis kesulitan belajar siswa kelas 3 SDI MIftahul Huda Plosokandang Kedungwaru Tulungagung di Masa pandemi Covid-19, maka disarankan: (1). Guru lebih memperhatikan satu persatu siswa yang belum mampu membaca. Guru dapat memberikan tambahan waktu belajar setelah setelah belajar kelompok, atau ketika kegiatan pembelajaran siswa yang tidak dapat membaca di tempatkan dengan teman sebangku yang bisa membaca agar siswa tersebut dapat menjadi 
guru sebaya bagi siswa tersebut (2). Guru lebih memberikan bimbingan dan perhatian kepada siswa yang belum mampu membaca menulis dengan baik, misalnya ketika siswa menulis guru berkeliling melihat siswa satu persatu, jika siswa tersebut melakukan kesalahan ketika menulis, guru membenarkan.

\section{DAFTAR PUSTAKA}

Abdurrahman, S. dan. (2009). Metode Penelitian. Jakarta: Rineka Cipta.

Arikunto, S. (2016). Prosedur Penelitian Suatu Pendekatan Praktik. Jakarta: Rineka Cipta.

Cahyati, N., \& Kusumah, R. (2020). Peran Orang Tua Dalam Menerapkan Pembelajaran Di Rumah Saat Pandemi Covid 19. Jurnal Golden Age, 4(01), 4-6. https:/ / doi.org/10.29408/jga.v4i01.2203

Fitri, A. Z., \& Haryanti, N. (2020). Metodologi Penelitian Pendidikan. Malang: Madani Media.

Husein, M. Bin. (2020). Kata kunci: Identifikasi, Kesulitan Belajar, Siswa. Kesulitan Belajar Pada Siswa Sekolah Dasar: Studi Kasus Di Sekolah Dasar Muhammadiyah Karangwaru Yogyakarta Difficulty, 6(1), 56-67.

Jamal, F. (2014). Analisis Kesulitan Belajar Siswa Pada Materi Peluang | 18. Jurnal MAJU (Jurnal Pendidikan Matematika), 1(1), 18-36.

Lilawati, A. (2020). Peran Orang Tua dalam Mendukung Kegiatan Pembelajaran di Rumah pada Masa Pandemi. Jurnal Obsesi: Jurnal Pendidikan Anak Usia Dini, 5(1), 549. https:// doi.org/10.31004/obsesi.v5i1.630

Moleong, L. J. (2002). Metodologi Penelitian Kualitatif. Bandung: PT. Remaja Rosdakarya.

Mulyadi. (2010). Diagnosis Kesulitan Belajar. Yogyakarta: Nuha Litera.

Nabila, H., \& Sulistiyaningsih, D. (2020). Analisis Kesulitan Belajar Matematika Dalam Pembelajaran Daring Berbantuan Microsoft Teams Kelas XI SMA Negeri 9, 62-71.

Putri, U. C., Saragih, E. M., \& Astuti, D. (2021). Analisis Kesulitan Belajar Via Whatsaap Siswa Kelas X Pada Masa Pandemi Covid-19, V(2), 137-144.

Sa 'adati, T. I. (2015). Intervensi Psikologis Pada Siswa Dengan Kesulitan Belajar (Disleksia, Disgrafia Dan Diskalkulia), 1(20), 13-37.

Sadikin, A., \& Hamidah, A. (2020). Pembelajaran Daring di Tengah Wabah Covid-19. Biodik, 6(2), 109-119. https:/ / doi.org/10.22437/ bio.v6i2.9759

Santrock. (2012). Psikologi Pendidikan. Jakarta: Salemba Humaika.

Satrianawati. (2012). Strategi pembelajaran bagi anak diskalkulia. Proseding Seminar Nasional PGSD UPY dengan Tema Strategi Mengatasi Kesulitan Belajar ketika Murid Anda seorang Disleksia, 46-53.

Simanjuntak, D. R., Ritonga, M. N., \& Harahap, M. S. (2020). Aanalisis Kesulitan Belajar Siswa Melaksanakan Pembelajaran Secara Daring Selama Masa Pandemi Covid-19. Mathematic Education Journal)MathEdu, 3(3), 142-146. Diambil dari http:/ /journal.ipts.ac.id/index.php/

Siregar, S. (2017). Metode Penelitian Kuantitatif: dilengkapi dengan perbandingan perhitungan manual dan SPSS. Jakarta: Kencana,.

Subarkah, M. A., \& Salim, A. (2021). “Analisis Kesulitan Belajar Peserta Didik Dalam Pembelajaran Jarak Jauh (Pji) Di Tengah Pandemi Covid-19". Rausyan Fikr: Jurnal Pemikiran dan Pencerahan, 17(1). https:/ / doi.org/10.31000/rf.v17i1.4184

Sugiyono. (2015). Metode Penelitian Kuantitatif Kualitatif R \& D. Bandung: Alfabeta.

Sukmadinata, N. S. (2011). Metode Penelitian Pendidikan. Bandung: PT. Remaja Rosdakarya.

Tanzeh, A. (2009). Pengantar Metodologi Penelitian. Yogyakarta: Teras.

Wijaya, E. (2020). Identification and Intervention of Specific Learning Disorder in Children. Damianus Journal Of Medicine, 19(1), 70-79.

Winarti, P. (2021). Analisis Kesulitan Belajar Mahasiswa dalam Perkuliahan Konsep Dasar 
IPA Fisika Secara Daring di Masa Pandemi Covid-19. Jurnal Komunikasi Pendidikan, 5(1), 93. https:/ / doi.org/10.32585/jkp.v5i1.1076

Zamzami, Sakdiah, \& Nurbaiza. (2020). Analisis Faktor Kesulitan Belajar Mata Pelajaran Biologi Siswa Kelas X SMA Negeri 1 Krueng Barona Jaya Kabupaten Aceh Besar. Jurnal Dedikasi Pendidikan, 4(1), 123-133. Diambil dari http:/ /jurnal.abulyatama.ac.id/index.php/dedikasi 